\title{
Drug Discovery and Ayurveda: Win-Win Relationship Between Contemporary and Ancient Sciences
}

\author{
Bhushan Patwardhan ${ }^{1}$ and Kapil Khambholja ${ }^{2}$ \\ ${ }^{1}$ Symbiosis International University, Pune, \\ ${ }^{2}$ Novartis Healthcare Pvt. Limited, Hyderabad, \\ India
}

\section{Introduction}

The present medicinal system is dominated by the Allopathy or western medicine which is prominently taught and practiced in most of the countries world wide. This system is still evolving and during last few decades focus was based on chemical origin of most of the medicines. Thus majority of drugs in current practice are from synthetic origin. Even so, a large number of these synthetic molecules are based directly or indirectly on natural products or phytoconstituents (Gupta et al. 2005; Harvey 2008). The interesting question is what type of medicines were people using for thousands of decades? Another interesting futuristic question is - What type of medicine / therapy would emerge and sustain in future? Answers to such questions can be obtained by doing a systemic review of existing scientific literature and also by making a forecast based on emerging technologies based on genetic sciences. Another important arena of brainstorming is how we link such questions with each other. We need to understand medicines or systems those were existing in use before emergence of current "synthetic era" and visualize the future of medicine and health care in the "technology era". The linkage between "the past" and "the future" of medicine is much more important and can give us "new directions" for better understanding health, disease and possible solutions.

Ayurveda, one of the oldest systems used by mankind for well being(Sharma 1995), originated in ancient India many thousand years ago (about $4500 \mathrm{BC}$ as agreed by most scientists). The origin, development, existence and even practice of Ayurveda has many dimensions and complex theories based on religions, faith and ancient Vedic science (Patwardhan \& Mashelkar 2009). Discussion on all these aspects is beyond the scope of this book chapter. Ayurveda, as a system of medicine, is one of the official systems of medicine in India (Mashelkar 2008) and is also widely practiced in many other countries (Mashelkar 2008). Evidence for effectiveness of many ayurvedic drugs and therapies is being generated rapidly from many research institutes and also there are projects under way to decipher unanswered questions related to Ayurveda. In this chapter we have tried to cover different but important aspects which give us a futuristic vision. After giving an overview of basics of Ayurveda, a comprehensive review of current status of research in Ayurveda is attempted. In later part of the chapter a dialogue on the key term "Drug Rediscovery" is being 
presented for the first time with a scientific perspective. The later part of the chapter also covers futuristic discussion where possibilities of linking Ayurveda with drug discovery process are described. We have tried to lay down conceptual framework for win-win relationship between ancient and contemporary health care sciences backed by strong scientific evidence being generated in recent years. We hope to provide innovative material for use in further development by scientific fraternity for ultimate benefit of health care and humanity.

\subsection{Introduction to Ayurveda}

There exist a plethora of information on Ayurveda through many books and commentaries published in past few decades. Most of these books are based on the traditional books which are thought to carry the knowledge and know-how of Ayurveda which, in ancient time, was existing in the form of memorised shlokas and manuscripts written in Sanskrit language. In this part of the chapter we have tried to present brief and comprehensive introduction to Ayurveda and its' fundamentals. The information provided is just a drop in the ocean and represents only that which is relevant to understanding the concept of Ayurveda and its further use in drug discovery process.

\subsection{What is Ayurveda?}

Ayurveda literally means "science of life" in Sanskrit (Ayur: Life; Veda: Science). It is not only a medical system but a way of life. As discussed earlier Ayurveda aims at a holistic management of health and diseases. It is widely practiced in the Indian subcontinent and is also one of the official systems of medicine in India. Its concepts and approaches are considered to have been perfected between 2500-500 BC.

Charak Samhita and Sushrut Samhita (100-500 BC) are the two main Ayurvedic classics, wherein more than 700 plants along with their classification, pharmacological and therapeutic properties have been described. Ayurveda during course of ancient times developed as sound scientific system and it is evident as it is divided into eight major disciplines known as Ashtanga Ayurveda. It is important to note that these specialisations or super specialisations were in existence and practiced by experts hundreds of years before the emergence of modern Anatomy, physiology and contemporary medicinal system!

\subsection{Fundamentals and perspectives}

\subsubsection{Ashtanga Ayurveda: Specialities of knowledge in Ayurveda}

Eight major divisions of Ayurveda have been described and followed for specialized knowledge. These categories are:

1. Kayachikistsa : The closest synonym would be internal medicine,

2. Shalya: General Surgery,

3. Shalakya: Speciality dealing with head and neck disorders,

4. Kaumar-bhritya: obstetrics and pediatrics

5. Rasayana: geriatrics and rejuvenative/reparative medicine

6. Vajikaran: Sexology and reproductive medicine,

7. Agad-Tantra: the body of knowledge on poisons, venoms and toxic substances,

8. Bhuta-Vidya: infectious diseases and mental illness. The fact that such a systemic categorization was established so early speaks of the knowledge and skills being central to the practice of Ayurveda. 
Another fundamental concept of Ayurveda is the well defined system for classifying the individuals on basis of their body constitution, physiology and other relevant factors. The concept of "Prakruti" is thought to be at the base of many important steps in Ayurvedic diagnosis and therapy.

Prakriti is a consequence of the relative proportion of three entities (Tri-Doshas), Vata (V), Pitta (P) and Kapha (K), which are not only genetically determined (Shukra Shonita), but also influenced by environment (Mahabhuta Vikara), maternal diet and lifestyle (Matur Ahara Vihara), and age of the transmitting parents (Kala -Garbhashaya).

In an individual, the Tri-Doshas work in conjunction and maintain homeostasis throughout the lifetime starting from fertilization. Distinct properties and functions have been ascribed to each Dosha. For instance, Vata contributes to manifestation of shape, cell division, signaling, movement, excretion of wastes, cognition and also regulates the activities of Kapha and Pitta. Kapha is responsible for anabolism, growth and maintenance of structure, storage and stability. Pitta is primarily responsible for metabolism, thermo-regulation, energy homeostasis, pigmentation, vision, and host surveillance.

\subsection{Drugs of Ayurveda}

Drugs used in Ayurvdea are mostly herbs (crude or processed), minerals products, metals (in different oxidised forms prepared by specialised manufacturing techniques) and also some times animal products. It is to be noted that in many instances a combination of one or more of above type of drugs are prescribed. As per Ayurveda- drugs alone cannot fulfil the goal of achieving, improving or maintaining the healthy state of the body. The lifestyle, food habits, environment and more importantly the mind plays an important role in Health. Thus the Vaidya (Ayurvedic physician) suggests a complete regime which is composed of a set of ayurvedic drugs (herbs/ herbo-mineral formulations) to be taken in specified manner in combination of food and life style changes are to be followed strictly, to achieve a healthy state of mind and body.

In last few years lots of research has been undertaken on medicinal properties, possible mechanisms and other relevant information on many popular herbs mentioned in traditional texts and used by Vaidyas. These research projects, mainly pre-clinical studies, help to generate evidence behind ayurvedic drugs' clinical use. Many interesting leads are emerging for further drug discovery from Ayurvedic drugs (Patawardhan et al. 2004,). These contributions are sometimes forgotten in the current dominance of the reductionist paradigm. Table 1 enlists some of the Ayurvedic herbs, which have been widely used and subject to pharmacological research. The structural modifications of active principles of these plants have led to a plethora of new "chemical" drugs and still there exist a vast unexplored arena for SAR based studies which may lead to unique molecules with unprecedented safety and efficacy. Since many decades several of these plants are being globally used by thousands of licensed Vaidyas and other practitioners and even as a part of household tradition. Looking into this background it is desirable to understand the Ayurvedic properties of herbs. This approach would assist in evolving innovative combinations, investigate new uses and conduct clinical trials with appropriate targets. As for example, a judicious and standardized combination of Aloe vera gel and Curcuma longa rhizome powder may yield a potent wound and burn healing new product. Similarly, a combination of Glycyrrhiza glabra and Zingiber officinale would be more useful in acid-peptic disease than the single ingredients. But any such combination must have a rational Ayurvedic basis, rather than herbal concoctions. Understanding the ayurvedic basis of any 
combination of herbs and its use in different condition requires knowledge of ayurvedic fundamentals and its correlation with contemporary concepts. Table 1 represent some examples of current evidence for ayurvedic drugs and their untapped potential yet to be established extending their scientific basis from Ayurveda (Vaidya AB 2006).

For further information and detailed knowledge readers are advised to study following subjects / specialisations of Ayurveda.

\subsection{Ayurvedic pharmaceuticals}

Bhaisajya Kalpana (Ayurvedic Pharmaceutics) forms a branch of Ayurveda, which mainly deals with collection and selection of ayurvedic drugs, purification as well as preparation, preservation, besides mode of administration and dosage specification. The ancient Ayurvedic scholars were very much rational and had a strong scientific background in fundamental principles, which are concerned with drug manufacturing.

Dravyagunavigyana includes identification (pharmacognosy-Namarupa vigyanya), preparation (pharmacy-Kalpa Vigyana) and administration (clinical pharmacology-Yoga Vigyana). The later deals with the effects of drugs on various systems (pharmacodynamicsGunakarma Vigyana) and their application in different diseases (therapeutic-Pryoga Vigyana)

\begin{tabular}{|l|l|l|}
\hline Ayurvedic Plant & Impact & Untapped potential \\
\hline Aloe vera & Cosmetopharmaocolgy/ Burns & Menopause/Andropause \\
\hline Atropa belladona & Acetyl choline pharmacology & Cigarrete for asthama \\
\hline Azadirachta indica & Antiinsect/Antifungal & Head and neck cancer \\
\hline Cassia angustifolia & Laxative/Indigetion & Chronic infections \\
\hline Curcuma longa & Antiinflammatory/Antidiabetic & Cancer \\
\hline Commiphora wightii & Antiarthritic/Obesity & Tuberculosis/Anti cancer \\
\hline Glycyrrhiza glabra & Peptic ulcer/Sore throat & Anti viral/Anti cancer \\
\hline Psoralea coryllifolia & Leucoderma/Psoriasis & Antimicrobial/Alopecia \\
\hline Rauwolfia serpentina & Antihypertensive/tranquillizer & Antivenom \\
\hline Strychnos nux-vomica & Digestive/Nervine tonic & Glycinergic receptors \\
\hline Tinospora cordifolia & Immuostimulant/Anticancer & Hepatoprotective \\
\hline Withania somnifera & Sedative/Phytoestrogen & Anticancer \\
\hline Zingiber officinalis & Indigetion/Nausea & Arthritis \\
\hline
\end{tabular}

Table 1. Ayurvedic plants and impact on therapy and drug discovery

\section{Contemporary drug discovery / development research on Ayurvedic concepts and medicines}

As discussed above Ayurvedic concepts differ significantly when it comes to diagnosis, use of drugs or even treatment pedagogy. It is well-known that Ayurveda tries to heal or cure 
any disease condition from its grass-root level. It means, it does not only remove the symptoms of the condition, but also alleviates the cause or factors behind the disease. In this part of the chapter we would share and discuss few examples of research done on ayurvedic concepts and medicines using contemporary technologies or methodologies.

\subsection{Exploring targets - Understanding mechanisms}

There are many studies reported where preclinical or even clinical evidence has been generated for understanding targets or even mechanisms for Ayurvedic therapies. Another important aspect of research is to correlate ayurvedic fundamentals behind etiology, disease progression and its possible interventions in terms of contemporary medical/life science.

\subsection{Correlating ancient science with contemporary pathophysiology and medicinal system}

An article published by Sharma and Chandola, discusses the details of "Prameha" of Ayurveda and its correlation with obesity, metabolic syndrome, and diabetes mellitus (Sharma\& Chandola 2011). The authors have given scientific basis of correlation and have described etiology, classification, and pathogenesis of these conditions both in terms of ayurvedic and modern concepts. According to this article there are 20 subtypes of Prameha due to the interaction of the three Doshas and 10 Dushyas (disturbed functioning of the principles that support the various bodily tissues); several of these subtypes have sweet urine, whereas some of them have different coloration of the urine, highlighting the inflammatory conditions involved in the metabolic syndrome. This disease has close ties to Sthaulya (i.e., obesity). With regard to diabetes mellitus, Sahaja Prameha and Jatah Pramehi correlate with type 1 diabetes; Apathyanimittaja Pramehacorrelates with type 2 diabetes. Madhumeha is a subtype of Vataja Prameha (Prameha withVata predominance) that can occur as the terminal stage of type 2 diabetes (in which insulin is required), or as type 1 diabetes beginning in early childhood. The latter is defined as Jatah Pramehi Madhumehino in Charaka Samhita, one of the classical Ayurvedic texts. The authors have concluded that various dietary, lifestyle, and psychologic factors are involved in the etiology of Prameha, particularly in relation to disturbances in fat and carbohydrate metabolism. The ancient Ayurvedic knowledge regarding Prameha can be utilized to expand the current understanding of obesity, metabolic syndrome, and diabetes.

\subsection{Discovery through pre-clinical studies for understanding mechanism and targets for Ayurvedic drugs}

As discussed earlier there are many papers being published regularly in national and international journals which provide evidence based on pre clinical studies and also some times provide probable mechanism of the ayurvedic drug / formulation under study. Few such examples are quoted here to reiterate the fact that ayurvedic drugs and therapies are having sound scientific background and one of the primary things remaining is to generate evidence so as to understand their utility and mechanism from contemporary science's point of view. In 2009 our team published results for understanding the immunomodulatory effect of "Shatavri" (Asparagus racemosus). Shatavri is one of the reputed and widely used rasayana herb of Ayurveda and is responsible for providing rejevunating effect along with other beneficial effects. In this article mixed Th1/Th2 activity of shatavri extracts is proven supporting its immunoadjuvant potential (Gautam et al. 2009). 
In another mechanistic study Chondroprotective potential of Extracts of Almalki Fruits (Phyllanthus emblica) in Osteoarthritis was undertaken to understand mechanism behind the traditional use of Almalki. Chondroprotection was measured in three different assay systems. First, the effects of fruit powder were studied on the activities of the enzymes hyaluronidase and collagenase type 2 . Second, an in vitro model of cartilage degradation was set-up with explant cultures of articular knee cartilage from osteoarthritis patients. Cartilage damage was assayed by measuring glycosaminoglycan release from explants treated with/without $P$. emblica fruit powders. Aqueous extracts of both fruit powders significantly inhibited the activities of hyaluronidase and collagenase type 2 in vitro. Third, in the explant model of cartilage matrix damage, extracts of glucosamine sulphate and selected extract exhibited statistically significant, long-term chondroprotective activity in cartilage explants from $50 \%$ of the patients tested (Sumantran et al. 2008).

\subsection{Clinical evidence for medicinal uses of Ayurvedic drugs}

Apart from pre-clinical studies many clinical studies of various depths are also being reported recently. Additionally the Government of India supported Department of AYUSH undertakes many clinical research based projects on prioritised ayurvedic medicines and formulations. One of the clinical studies we would like to quote here as reference is for studying efficacy of standardised ayurvedic formulation in arthritis. The multidisciplinary "New Millennium Indian Technology Leadership Initiative" Arthritis Project was supported by Government of India. It included randomised controlled exploratory trial with Zingiber officinale and Tinospora cordifoliaas as main drugs in the formulations under study. Total 245 eligible patients suffering from symptomatic osteo arthritic knees gave consent for it and were randomized into seven arms ( 35 patients per arm) of a double blind, parallel efficacy, and multicentre drug trial of sixteen weeks duration. The trial was controlled for placebo and glucosamine sulphate use. No dietary or other restrictions were advised. The groups matched well at baseline. There were no differences between the groups for patient withdrawals (total forty three) or adverse events (AE) which were all mild. In an intentionto-treat primary efficacy analysis, there were no significant differences $(P<.05)$ for pain (weight bearing) and WOMAC questionnaire (knee function); a high placebo response was recorded. Based on better pain relief, significant $(\mathrm{P}<.05)$ least analgesic consumption, and improved knee status, one of the formulations under study " $\mathrm{C}$ " formulation was selected for further development. This study gives overview suggesting that how the clinical research on ayurvedic herbs or formulations can generate the evidence and also in understanding their possible mechanism of action (Chopra et al. 2011).

\subsection{Clinical evidence for Ayurvedic therapy}

As discussed earlier most of the time Ayurvedic physicians undertake different approaches for treatment where multiple drugs or formulations are used at one or different stages therapy. One such popular approach in Ayurveda is "Pachkarma therapy" which is used for variety of conditions where detoxification is required to cope up with stress or unbalanced physiology. Ayurvedic drugs or formulations used in such therapy can lead to a very different approach of drug discovery where multiple drugs are working together on multiple targets to achieve the objective of balancing the body physiology.

One such study is reported by Tripathi et al. (2010). This was a comparative clinical trial on the role of Panchakarma therapy and Unmada Gajankusha Rasa in the cases of major depressive disorder vis-à-vis kaphaja Unmada. 


\subsection{Safety pharmacology and drug interaction studies as part of drug discovery based on ayurvedic drugs}

In contemporary Drug discovery programs safety has prime importance and any molecule must have a favorable risk benefit ratio to be considered and approved as drug. Even though ayurvedic drugs and/or formulations are in use by public and vaidyas since antiquities, most of them have a proven record of safety and tolerability. Any change or deviation in method of preparation or use other then that mentioned in traditional text requires additional studies to evaluate safety. Another safety aspect includes understanding of drug interactions if ayurvedic drugs are to be taken with other form of medicines. These sub parts of drug discovery process can be addressed by undertaking invitro toxicology studies and pharmacokinetic studies to understand drug interactions. In one of the studies we have reported Safety Pharmacology and Drug Interaction aspects of Cassia auriculata. In this study routine safety pharmacology with focus on cardiovascular variables and pharmacokinetic herb-drug interaction studies on rats fed with standardized traditional hydro-alcoholic extract and technology-based supercritical extract of Cassia auriculata for 12 weeks were undertaken. These studies indicate that both these extracts are pharmacologically safe and did not show any significant adverse reactions at the tested doses. The traditional hydro-alcoholic extract did not show any significant effect on pharmacokinetics; however, the technology-based supercritical extract caused a significant reduction in absorption of Metformin (Puranik et al. 2011).

These and many other such studies describe the way of incorporation of safety aspect in drug discovery process for Ayurvedic drugs.

\section{Concept of "Drug rediscovery"}

Contemporary Drug discovery and development (DD) process is becoming longer and expensive. Establishing the right balance between efficacy and safety is the crucial part of DD process. As the chemical entity under study would be completely new and no prior human exposure is reported, there are chances of many unexpected side effects being observed at various stages of development. These require multiple efforts for optimisation of the molecule for its safety and efficacy and many times the molecule under study has to be dropped from study due to high toxicity or side effects.

Most ayurvedic drugs / herbs are in use since times immemorable and experience of thousands of physicians is available to vindicate their safety and efficacy. Thus drug discovery process needs to be modified if benefits from Ayurvedic science are to be tapped. Many scholars have previously reported different approaches for this. "Reverse pharmacology" approach starts with clinical studies and goes upto the mechanistic preclinical studies (Patwardhan 2004).

Here we deploy a term "Drug rediscovery" which is more relevant for research involving ayurvedic herbs and drugs. As ayurvedic drugs are already in use as part of medicinal system any further research on these drugs would aid only in understanding their mechanisms and / or help in optimising their doses either alone or in combination. Thus the term "Drug rediscovery" would help differentiate process of discovering a drug from totally new chemical entity from the process of understanding a drug which is not totally new to mankind.

Another extension of Drug rediscovery from ayurvedic drugs can be done for benefit of contemporary science of medicine and that would be "stage 2 drug discovery" based on 
results of research done during drug rediscovery of ayurvedic drugs and herbs. This stage 2 DD would start only after bio-marker based research which is a part of Drug rediscovery of ayurvedic drugs. This may generate to newer leads with multiple targets and can give new direction to speed up the existing discovery path adopted. This concept is explained in Table 2.

Stage I:

\section{DRUG REDISCOVERY on Ayurvedic Drugs}

-Proven Ayurvedic drugs to be studied for phytoconstituents

- Activity guided fractionation of Biomarkers

- SAR studies of active constituents

- Mechanistic studies (Preclinical \& Clinical)

-All these leads to optimized therapy based on new evidences to be clubbed with traditional knowledge

\section{Stage II:}

\section{Drug Discovery: Outputs of SAR studies (Stage I) from Ayurvedic} Drug rediscovery program

\section{- New LEADS}

- Lead optimization and study on new molecule with unique safety and efficacy profile

\section{Outputs of Mechanistic studies of Ayurvedic Drug rediscovery program}

- Unique mechanism with multiple targets.

- New target identificaton and validation.

- Systems biology approach potentiating:

- Single drug / molecule working on multiple targets or even multiple systems.

- Multi herb-Multi target

Table 2. Unique potential of Ayurvedic Drugs for Drug (Re)discovery

\subsection{Accelerated clinical research}

The process of rediscovering a drug on basis of its ayurvedic origin involves reverse pharmacology and requires different approaches for undertaking clinical research. One of 
the approaches can be retrospective study based on hospitals' or clinicians' (vaidya in most of the cases) practice of particular disease or herb. This would be little difficult looking into differences in documentation and record keeping practices in most of the parts of India where Ayurveda is regularly practiced. Another approach for undertaking clinical study can be based on Reverse pharmacology where drug under study can be selected on basis of its clinical use and field experience. We have already discussed one such study earlier in this chapter where randomized, controlled exploratory clinical study on ayurvedic formulation was done for its use in osteoparthritic conditions (Chopra et al. 2011). This study along with standardization of formulation was completed in 23 months and thus the time of generation of evidence is comparatively low as that of contemporary discovery of newer molecules. Even WHO had published guideline mentioning different requirements for clinical research on Traditional medicines (2000). Thus the concepts of "Reverse pharmacology" and "Drug Rediscovery" through Ayurvedic drugs can significantly reduce the time-lag between induction of research project and clinical evidence generation through scientifically designed clinical research.

\subsection{AyuGenomis: Role in future of drug discovery}

Biotechnology with its specialisations like genomics, proteomics, genetic engineering etc. has made immense advances in deciphering diseases conditions, disease progression, prognosis and even up-to certain level cure for particular conditions. Genomics can play important role both in prevention and treatment of many diseases (Steinberg et al. 2001). The advanced technologies used in genomics and related sciences can help understanding role of genes in diseases and health. The use of these technologies and concepts for generating scientific evidence behind concepts of Ayurveda can open up many interesting avenues.

Structural and functional genetic differences in humans can take the form of single nucleotide polymorphisms (SNP), copy number variations (CNVs), and epigenetic or gene expression modifications. As per current research, in human $99.5 \%$ genetic similarity is found and almost all physiological or anatomical variations amongst person to person are due to $0.5 \%$ diversity in single nucleotide polymorphism (SNP) and other variations in nucleotides (Levy et al. 2007). These inherited inter-individual variations in DNA sequence contribute to phenotypic variation, influencing an individual's anthropometric characteristics, risk of disease and response to the environment. Characterizing genetic variation may bring improved understanding of differential susceptibility to disease, differential drug response, and the complex interaction of genetic and environmental factors, which go to produce each phenotype.

Ayurveda, the traditional system of Indian medicine, Traditional Chinese medicine and Korean medicine all have well-defined systems of constitutional types used in prescribing medication bearing distinct similarities to contemporary pharmacogenomics. The pharmacognenomics can become useful for understanding genetic basis of concept of "Prakriti". This part of the chapter would discuss about how Pharmacogenomics and Ayurveda can be researched together for unpacking vast possibilities of integrated science. According to Ayurveda an individual's basic constitution to a large extent determines predisposition and prognosis to diseases as well as therapy and life-style regime. Importance of such individual variations in health and disease is an important basic principle of ayurveda and was underlined by Charaka sometime 4000 years ago as follows: 
'Every individual is different from another

and hence should be considered as a different entity.

As many variations are there in the Universe, all are seen in Human being'.

In the Ayurveda system of medicine, predisposition to a disease as well as selection of a preventive and curative regime is primarily based on phenotypic assessment of a person which includes one's body constitution termed "Prakriti". The concept of Prakriti is already discussed in detail earlier in this chapter.

The phenotypic diversity, according to Ayurveda, is a consequence of a continuum of relative proportions of Doshas resulting in seven possible constitutional types namely Vata (V), Pitta(P), Kapha(K), Vata-Pitta, Pitta-Kapha, Vata-Kapha and Vata-Pitta-Kapha. Amongst these, the first three are considered as extremes, exhibiting readily recognizable phenotypes, and are more predisposed to specific diseases.

Better characterization of the human genome has improved the scientific basis for understanding individual variation. The Ayurvedic Prakriti concept should be examined from a genomic perspective. Permutations and combinations of V, P, K attribute characters along with other host factors such as tissue status (Dhatusarata), twenty Gunas, digestive capacity and metabolic power (Agni), psychological nature (Manas Prakriti), habitat (Desha), and season (Kaala), lead to sufficient numbers of variants to define a unique constitution for every individual. Ayurveda thus describes the basis of individual variation(Bhushan 2007).

In the realm of modern predictive medicine, efforts are being directed towards capturing disease phenotypes with greater precision for successful identification of markers for prospective disease conditions.

Ayurveda has been investigated for this purpose, based on the hypothesis that Prakriti types $(\mathrm{V}, \mathrm{P}$ and $\mathrm{K}$ ) may offer phenotypic datasets suitable for analysis of underlying genetic variation. As a proof of concept, in the first study done by us, we evaluated 76 subjects both for their Prakriti and HLA DRB1 types, finding significant correlations in support of it (Patwardhan et al. 2005). The study concluded that Ayurveda based phenomes may provide a model to study multigenic traits, possibly offering a new approach to correlating genotypes with phenotypes for human classification.

The three major constitution types described in Ayurveda have unique putative metabolic activities, $\mathrm{K}$ being slow, $\mathrm{P}$ fast, while $\mathrm{V}$ is considered to have variable metabolism. We hypothesized that this might relate to drug metabolism and genetic polymorphism of drug metabolizing enzymes (DME). Inter-individual variability in drug response can be attributed to polymorphism in genes encoding different drug metabolizing enzymes, drug transporters and enzymes involved in DNA biosynthesis and repair. Gene polymorphisms precipitate in different phenotypic subpopulations of drug metabolizer. Poor metabolizers (PM) have high plasma concentration of the drug for longer periods and so retain drugs in the body for longer times. Intermediate metabolizers retain drugs in the body for normal time periods. Extensive metabolizers (EM) retain drugs in the body for the least time, plasma concentrations being high for shorter periods.

In another study we investigated the distribution of drug metabolizing enzymes CYP2C19 and CYP2C9 genotypes in 132 healthy individuals of different Prakriti classes(Ghodke et al. 2009). The results obtained suggest possible association of CYP2C19 gene polymorphism with Prakriti phenotypes.

Overview of few such studies are given in Table No 3 which gives successful lead to new directions for further research. 
Drug Discovery and Ayurveda: Win-Win

\begin{tabular}{|c|c|c|c|c|}
\hline medicine/intervention & target/enzyme & no. of person & Output & Ref. no \\
\hline $\begin{array}{l}\text { corelation between Human } \\
\text { Leucocytes Antigen(HLA) } \\
\text { and prakriti type }\end{array}$ & HLA DRB1 gene & $\begin{array}{l}\text { Total } 76 \text { person } \\
10 \text { - vata } \\
32 \text { - kapha } \\
34 \text { - pitta } \\
\text { prakriti }\end{array}$ & $\begin{array}{l}\text { There is complete absence } \\
\text { of HLA DRB1*02 in Vata } \\
\text { and HLA DRB1*13 in } \\
\text { Kapha }\end{array}$ & $\begin{array}{l}\text { (Bhushan et } \\
\text { al. 2005) }\end{array}$ \\
\hline $\begin{array}{l}\text { correlation between } \\
\text { CYP2C19 Gene } \\
\text { Polymorphism and prakriti } \\
\text { type associated with } \\
\text { metabolic activity }\end{array}$ & $\begin{array}{l}\text { CYP2C19 } \\
\text { (a variant of the } \\
\text { enzyme, } \\
\text { cytochrome P450) }\end{array}$ & $\begin{array}{l}132 \text { healthy } \\
\text { subjects }\end{array}$ & $\begin{array}{l}\text { The extensive metabolizer } \\
\text { (EM) genotype was } \\
\text { predominant in Pitta } \\
\text { Prakriti }(91 \%) \text {, Poor } \\
\text { metabolizer }(31 \%) \text { in } \\
\text { Kapha Prakriti when } \\
\text { compared with Vata } \\
(12 \%) \text { and Pitta Prakriti } \\
(9 \%) \text {. }\end{array}$ & $\begin{array}{l}\text { (Ghodke et al. } \\
\text { 2009) }\end{array}$ \\
\hline $\begin{array}{l}\text { Ayurveda's 'Rasa' } \\
\text { correspondence with } \\
\text { pharmacological activity }\end{array}$ & $\begin{array}{l}\text { Ibuprofen, } \\
\text { oleocanthal (from } \\
\text { olive oil) }\end{array}$ & & $\begin{array}{l}\text { substances' similarities of } \\
\text { 'Rasa' may indicate } \\
\text { similar pharmacological } \\
\text { activity \& assumes a new } \\
\text { significance to distinguish } \\
\text { all the kinds of molecule }\end{array}$ & $\begin{array}{l}\text { (Joshi et al. } \\
\text { 2007) }\end{array}$ \\
\hline $\begin{array}{l}\text { The molecular correlation } \\
\text { between the different } \\
\text { constitution types }\end{array}$ & $\begin{array}{l}\text { genome wide } \\
\text { expression levels, } \\
\text { biochemical and } \\
\text { hematological } \\
\text { parameters, Gene } \\
\text { Ontology (GO) and } \\
\text { pathway based } \\
\text { analysis }\end{array}$ & $\begin{array}{l}\text { Total } 96 \\
\text { individuals } \\
\text { Vata-39 } \\
\text { Pitta-29 } \\
\text { Kapha-28 }\end{array}$ & $\begin{array}{l}\text { The extreme constitution } \\
\text { types revealed differences } \\
\text { at gene expression level, } \\
\text { biochemical levels. It } \\
\text { provide a strong basis for } \\
\text { integration of this holistic } \\
\text { science with modern } \\
\text { genomic approaches for } \\
\text { predictive marker } \\
\text { discovery and system } \\
\text { biology studies. }\end{array}$ & $\begin{array}{l}\text { (Prasher } \\
\text { et al. 2008) }\end{array}$ \\
\hline $\begin{array}{l}\text { EGLN1 involvement in } \\
\text { high-altitude adaptation } \\
\text { revealed through genetic } \\
\text { analysis of extreme } \\
\text { constitution types defined in } \\
\text { Ayurveda }\end{array}$ & $\begin{array}{l}\text { EGLN1 is a key } \\
\text { oxygen sensor gene } \\
\text { inhibit hypoxia- } \\
\text { inducible factor } \\
\text { (HIF-1A). }\end{array}$ & $\begin{array}{l}24 \text { different } \\
\text { Indian } \\
\text { Populations }\end{array}$ & $\begin{array}{l}\text { TT genotype of rs } 479200 \\
\text { was more frequent in } \\
\text { Kapha types and } \\
\text { correlated with higher } \\
\text { expression of EGLN1, was } \\
\text { associated with patients } \\
\text { suffering from high- } \\
\text { altitude pulmonary } \\
\text { edema, whereas it was } \\
\text { present at a significantly } \\
\text { lower frequency in Pitta } \\
\text { and nearly absent in } \\
\text { natives of high altitude. }\end{array}$ & $\begin{array}{l}\text { (Aggarwal } \\
\text { et al. 2010) }\end{array}$ \\
\hline
\end{tabular}

Table 3. Advanced studies on Ayurvedic fundamentals 
Thus it can be summarised that identification of genetic variations underlying metabolic variability in Prakriti may provide newer approach to Pharmacogenomics. Extensive studies on Prakriti subtypes and genome wide single nucleotide polymorphism (SNP) mapping especially of other important DME polymorphisms like CYP2D6, CYP2C9, CYP3A4, TPMT, etc., would be useful to understand possible Prakriti pharmacogenomics relationship correlating genotype, Prakriti and drug metabolism.

Thus, these studies support that Ayurveda Classification is based on genome differentiation and having correlation with different drug responses and adverse effect. The Ayurvedic classification shows similar principle of pharmacogenomics for selecting "right drug, right dosage and to the right patient". There are many such studies required to prove the scientific basis of many of the un-deciphered complex Ayurvedic principles and fundamentals given in Vedic science of life. It seems that thousands of years before, Ayurvedic experts had known effect of genetic variation on physiology and pharmacology much more in details and current scientific tools fell short of understanding such complex concepts of Ayurveda.

An integration of traditional systems of medicine(Ayurveda, TCM, SCM, Kampo) with pharmacogenomics utilizes the advantage of high throughput DNA sequencing, gene mapping, and bioinformatics to identify the actual genetic basis of 'interindividual' and 'interracial' variation in drug efficacy and metabolism and holds promise for future predictive and personalized medicine.

Combining the strengths of the knowledge base of traditional systems of medicine with the dramatic power of combinatorial sciences and HTS will help in the generation of structureactivity libraries which will converge to form a real discovery engine that can result in newer, safer, cheaper and effective therapies.

The traditional systems of medicine in Asia (Ayurveda, TCM, SCM, Kampo) are considered great living traditions. They are all closely related to each other. For example, all are based on theories of constitution. All identify unique qualities of each individual, and state the necessity of developing personalized medicine in order to obtain optimal response to treatment. This is similar to the science of Pharmacogenomics, which tries to identify individual differences between patients connected to drug metabolism, efficacy and toxicity at the genomic level. Current research in 'Omics' is focusing on the polygenic approach using high throughput technology rather than the single gene approach.

Such research found a genetic basis for the classification of physical constitution in traditional medicine. "These observations are likely to have an impact on phenotypegenotype correlation, drug discovery, pharmacogenomics and personalized medicine." So, "Identifying genetic variations in Asia-based constitution may provide a newer approach to pharmacogenomics and help better understand the scientific classification basis of human population for better therapeutic benefits."

\section{Current status: Promises and bottle necks}

\subsection{Appraisals or evidence for importance of Ayurveda}

The evidence is what is required to prove an idea or concept or even a system. There exist plethora of evidence for scientific basis of Ayurveda (Mishra 2003; Patwardhan\& Mashelkar 2009; Vaidya AB 2006) and one needs to adopt an unbiased neutral opinion to see the promising way forward for drug discovery with support of Ayurveda. Because ancient sciences are not limited to one religion or geographical area, they should be used for benefit 
of health care system in totality. The promising outputs are already available where Ayurveda has given many miracle drugs like Ashwagandha (Withania somnifera, Family: Solanaceae), Guggul (Commiphora wightii, F: Burseraceae), Shatavari (Asparagus racemosus, F: Asparagaceae), Brahmi(Centella asiatica, F: Mackinlayaceae), Neem (Azadirachta indica, F: Meliaceae), Turmeric (Curcuma longa, F: Zingiberaceae), Isabgul (Plantago ovata, F: Plantaginaceae) so on and so forth. These drugs can be used both in traditional forms as well as in form of standardized semipurified or purified phytopharmaceuticals. These plants or their parts are regulated differently in different countries. As per Ayurvedic system of medicine they are licensed as drugs and are in Clinical use in India. As these drugs are not fully standardised or as currently there is no globally accepted common regulations for herbals they can be considered as herbal supplement or functional food etc. The research on preclinical, clinical, Phytochemical, Pharmacokinetics-Pharmacodynemics (PK-PD), safety pharmacology etc. for ayurvedic drugs and formulations are on surge and world needs to have more integrative and planned approach so as to leverage the benefit of this tie-up between ancient and contemporary sciences.

\subsection{Possible bottle necks}

As many concepts of Ayurveda are more of integrated nature it needs inputs from many branches of science. As for example personalized medicine concept is an integral part of Ayurveda and is based on "Prakriti" of an individual which affects the choice of medicine and the way the particular health condition is treated though Ayurveda. This paradigm is into its infancy in modern science where we are still trying to understand genetic variations and their links with diseases and physiology. One of the possible bottlenecks can be lack of scientific tools which help to understand the detailed concepts of Ayurveda.

Another bottle neck that is already under debate is "marker" based evaluation of herbs. Traditionally ayurvedic herbs are used in crude form (and not as isolated or purified compounds) and many a times in combination with other herbs or preparations and thus science behind chemistry of such complex mixtures is yet to be evolved. Even though Ayurveda has provided many promising leads in terms of isolated molecules it is different part of story where individual phytoconstituents are studied as drugs. Thus we need to differentiate between traditional ayurvedic drugs and modern form of phyto-constituent based drugs (Patwardhan\& Mashelkar 2009).

\section{Win-win situation for future of health care}

To conclude this chapter we would like to elaborate various points where ancient science of Ayurveda and contemporary health care stream can gain from each other for far reaching benefits and newer directions of drug discovery and health.

Table No. 4 discusses benefits that can be gained by Ayurveda and contemporary science.

\section{Disclaimer}

Dr Kapil M Khambholja is currently affiliated to Novartis Healthcare Pvt. Ltd., India and was earlier affiliated to S K Patel College of Pharmacetuical Education and Research, Ganpat University, India as an Asst. Professor. The views expressed in this chapter are purely of author him self and in no manner reflects views or opinion from affiliating company or organisation. 


\begin{tabular}{|c|c|c|}
\hline & Benefits for Ayurveda & $\begin{array}{c}\text { Benefits for drug discovery / } \\
\text { health care sciences }\end{array}$ \\
\hline $\begin{array}{l}\text { Benefits in } \\
\text { Chemistry } \\
\text { domain }\end{array}$ & 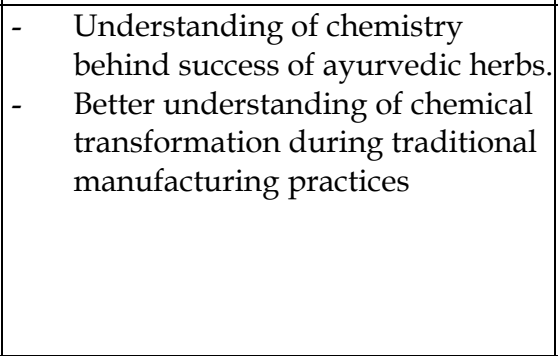 & 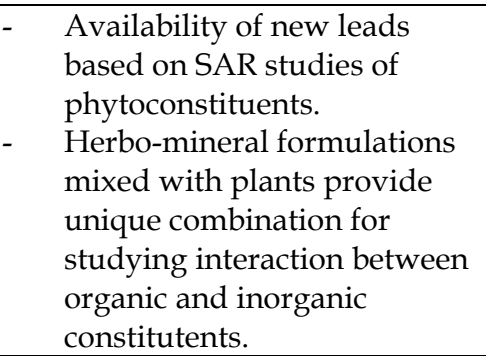 \\
\hline $\begin{array}{l}\text { Benefits in } \\
\text { Process } \\
\text { domain }\end{array}$ & 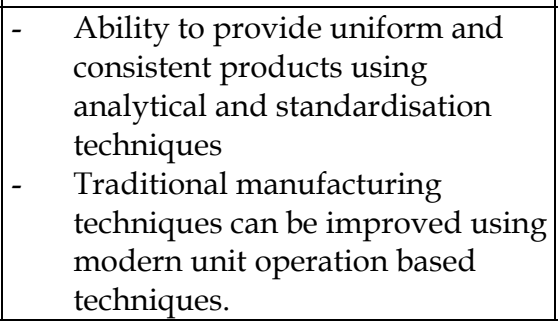 & $\begin{array}{l}\text { Traditional ayurvedic } \\
\text { manufacturing techniques } \\
\text { involve unique type of } \\
\text { processes which can form } \\
\text { basis of improved unique } \\
\text { processes of purification, } \\
\text { separation, manufacturing etc. }\end{array}$ \\
\hline $\begin{array}{l}\text { Benefits in } \\
\text { Life science } \\
\text { domain }\end{array}$ & 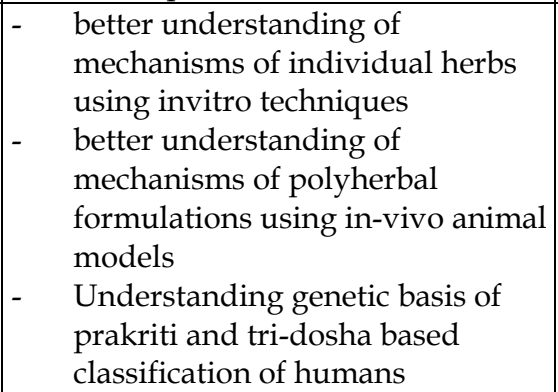 & 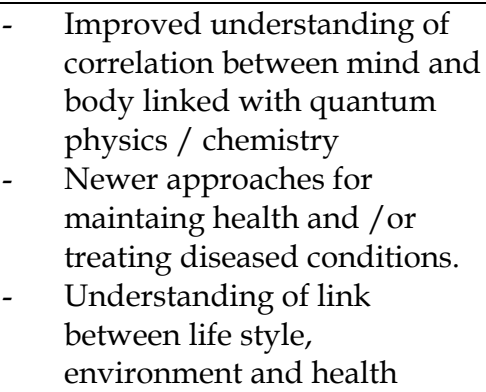 \\
\hline
\end{tabular}

Table 4. Win-win situation for Ayurveda, contemporary drug discovery process and health care sciences

\section{References}

(2000). General Guidelines for Methodologies on Research and Evaluation of Traditional Medicine. Geneva: World Health Organisation.

Aggarwal S, Negi S, Jha P, Singh PK, Stobdan T, Pasha MA, Ghosh S, Agrawal A, Prasher B , Mukerji M (2010). EGLN1 involvement in high-altitude adaptation revealed through genetic analysis of extreme constitution types defined in Ayurveda. Proc Natl Acad Sci U S A. Vol.107,No., 44, 18961-18966.1091-6490 (Electronic) 0027-8424 (Linking),

Patwardhan B (2007). Drug discovery and development: traditional medicine and ethnopharmacology. New Delhi: New India Publishing Agency.

Patwardhan B, Joshi K, Arvind C (2005). Classification of Human Population Based on HLA Gene Polymorphism and the Concept of Prakriti in Ayurveda. The Journal of Alternative and Complementary Medicine. Vol.11,No., 2, 349-353, 
Bhushan Patwardhan, Ashok Vaidya, Mukund Chorghade (2004). Ayurveda and natural products drug discovery. Current Science. Vol.86,No., 6, 789-799,

Chopra A, Saluja M, Tillu G, Venugopalan A, Sarmukaddam S, Raut AK, Bichile L, Narsimulu G, Handa R , Patwardhan B (2011). A Randomized Controlled Exploratory Evaluation of Standardized Ayurvedic Formulations in Symptomatic Osteoarthritis Knees: A Government of India NMITLI Project. Evidence-based Complementary and Alternative Medicine. Vol.2011,No.,

Gautam M, Saha S, Bani S, Kaul A, Mishra S, Patil D, Satti NK, Suri KA, Gairola S, Suresh K, Jadhav S, Qazi GN , Patwardhan B (2009). Immunomodulatory activity of Asparagus racemosus on systemic Th1/Th2 immunity: Implications for immunoadjuvant potential. Journal of Ethnopharmacology. Vol.121,No., 2, 241247.0378-8741,

Ghodke Y, Joshi K, Patwardhan B (2009). Traditional Medicine to Modern Pharmacogenomics: Ayurveda Prakriti Type and CYP2C19 Gene Polymorphism Associated with the Metabolic Variability. Evid Based Complement Alternat Med.No.1741-4288 (Electronic) 1741-427X (Linking),

Gupta R, Gabrielsen B , Ferguson SM (2005). Nature's medicines: traditional knowledge and intellectual property management. Case studies from the National Institutes of Health (NIH), USA. Curr Drug Discov Technol. Vol.2,No., 4, 203-219.1570-1638 (Print) 1570-1638 (Linking),

Harvey AL (2008). Natural products in drug discovery. Drug Discov Today. Vol.13,No., 19-20, 894-901.1359-6446 (Print) 1359-6446 (Linking),

Joshi K, Hankey A , Patwardhan B (2007). Traditional Phytochemistry: Identification of Drug by \&\#x2018;Taste\&\#×2019. Evidence-based Complementary and Alternative Medicine. Vol.4,No., 2, 145-148,

Levy S, Sutton G, Ng PC, Feuk L, Halpern AL, Walenz BP, Axelrod N, Huang J, Kirkness EF, Denisov G, Lin Y, MacDonald JR, Pang AWC, Shago M, Stockwell TB, Tsiamouri A, Bafna V, Bansal V, Kravitz SA, Busam DA, Beeson KY, McIntosh TC, Remington KA, Abril JF, Gill J, Borman J, Rogers Y-H, Frazier ME, Scherer SW, Strausberg RL, Venter JC (2007). The Diploid Genome Sequence of an Individual Human. PLoS Biol. Vol.5,No., 10, e254,

Mashelkar RA (2008). Second World Ayurveda Congress (Theme: Ayurveda for the Future) - Inaugural address: Part I. Evidence-based Complementary and Alternative Medicine. Vol.5,No., 2, 129-131.1741-427X,

Mishra L.(2003).Scientific basis of Ayurvedic Therapies, CRC Press, 0-8493-1366-X, New Yourk

Patwardhan B , Mashelkar RA (2009). Traditional medicine-inspired approaches to drug discovery: can Ayurveda show the way forward? Drug Discov Today. Vol.14,No., 15-16, 804-811.1878-5832 (Electronic)1359-6446 (Linking),

Prasher B, Negi S, Aggarwal S, Mandal AK, Sethi TP, Deshmukh SR, Purohit SG, Sengupta S, Khanna S, Mohammad F, Garg G, Brahmachari SK , Mukerji M (2008). Whole genome expression and biochemical correlates of extreme constitutional types defined in Ayurveda. J Transl Med. Vol.6,No., 48.1479-5876 (Electronic) 1479-5876 (Linking),

Puranik AS, Halade G, Kumar S, Mogre R, Apte K, Vaidya ADB , Patwardhan B (2011). Cassia auriculata: Aspects of Safety Pharmacology and Drug Interaction. Evidencebased Complementary and Alternative Medicine. Vol.2011,No., 
Sharma H , Chandola HM (2011). Prameha in Ayurveda: Correlation with Obesity, Metabolic

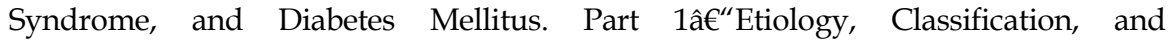
Pathogenesis. The Journal of Alternative and Complementary Medicine. Vol.17,No., 6, 491496,

Sharma P (1995). Charak Samhita. Varanasi, India: Chaukambha Orientallia.

Steinberg KK, Gwinn M , Khoury MJ (2001). The Role of Genomics in Public Health and Disease Prevention. JAMA: The Journal of the American Medical Association. Vol.286,No., 13, 1635,

Sumantran VN, Kulkarni A, Chandwaskar R, Harsulkar A, Patwardhan B, Chopra A, Wagh UV (2008). Chondroprotective Potential of Fruit Extracts of Phyllanthus emblica in Osteoarthritis. Evidence-based Complementary and Alternative Medicine. Vol.5,No., 3, 329-335,

Tripathi J, Reddy KRC, Gupta S , Dubey S (2010). A comparative clinical trial on the role of Panchakarma therapy and Unmada Gajankusha Rasa in the cases of major depressive disorder vis-\&\#224;-vis kaphaja Unmada. AYU (An international quarterly journal of research in Ayurveda). Vol.31,No., 2, 205-209,

Vaidya AB RA (2006). Evidences based Ayurveda Sorting fact from fantasy. In Ayurveda and its Scientific Aspects - Opportunities for Globalisation). New Delhi: Department of AYUSH and CSIR, pp. 1-30. 


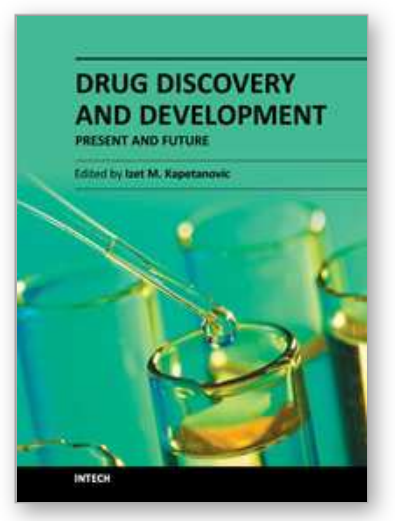

\author{
Drug Discovery and Development - Present and Future \\ Edited by Dr. Izet Kapetanović
}

ISBN 978-953-307-615-7

Hard cover, 528 pages

Publisher InTech

Published online 16, December, 2011

Published in print edition December, 2011

Drug discovery and development process aims to make available medications that are safe and effective in improving the length and quality of life and relieving pain and suffering. However, the process is very complex, time consuming, resource intensive, requiring multi-disciplinary expertise and innovative approaches. There is a growing urgency to identify and develop more effective, efficient, and expedient ways to bring safe and effective products to the market. The drug discovery and development process relies on the utilization of relevant and robust tools, methods, models, and validated biomarkers that are predictive of clinical effects in terms of diagnosis, prevention, therapy, and prognosis. There is a growing emphasis on translational research, a bidirectional bench to the bedside approach, in an effort to improve the process efficiency and the need for further innovations. The authors in the book discuss the current and evolving state of drug discovery and development.

\title{
How to reference
}

In order to correctly reference this scholarly work, feel free to copy and paste the following:

Bhushan Patwardhan and Kapil Khambholja (2011). Drug Discovery and Ayurveda: Win-Win Relationship Between Contemporary and Ancient Sciences, Drug Discovery and Development - Present and Future, Dr. Izet Kapetanović (Ed.), ISBN: 978-953-307-615-7, InTech, Available from:

http://www.intechopen.com/books/drug-discovery-and-development-present-and-future/drug-discovery-andayurveda-win-win-relationship-between-contemporary-and-ancient-sciences

\section{INTECH}

open science | open minds

\section{InTech Europe}

University Campus STeP Ri

Slavka Krautzeka 83/A

51000 Rijeka, Croatia

Phone: +385 (51) 770447

Fax: +385 (51) 686166

www.intechopen.com

\section{InTech China}

Unit 405, Office Block, Hotel Equatorial Shanghai

No.65, Yan An Road (West), Shanghai, 200040, China

中国上海市延安西路65号上海国际贵都大饭店办公楼 405 单元

Phone: +86-21-62489820

Fax: $+86-21-62489821$ 
(C) 2011 The Author(s). Licensee IntechOpen. This is an open access article distributed under the terms of the Creative Commons Attribution 3.0 License, which permits unrestricted use, distribution, and reproduction in any medium, provided the original work is properly cited. 